\title{
DR. MICHAEL P. JORDAN WINS AMERICAN AWARD
}

Michael Jordan, who teaches technical writing in the Faculty of Applied Sclence at Queen's University, has won one of the annual awards of the National Counc11 of Teachers of English (NCTE) Publication Awards Program In Technical and Scientific Communication. His article, "Short Texts to Explain Problem-Solution Structures--and Vice Versa," was judged Best Article on Reporting Formal Research.

The announcement pralsed Dr. Jordan: "The award winning calibre of your submission not only marks you as a leader within the discipline of techntcal communication, but also as one of the first persons recognized by the NCTE for professional excellence in scholarly publication."

The award was presented March 17 in Detrolt at the CTSC annual meeting during the Conference on College Composition and Communication.

Dr. Jordan's Ph.D. is in linguistics/English language and he specializes in information structures and coherence patterns in contemporary English prose--especially technical writing. He holds an Honorary Research Fellowship in Contemporary English Language at The Hatfleld Polytechnic, Hertfordshire, England, where he has done much of his recent research. He is a Fellow of the Institute of Scientific and Technical Communfcators (UK), and is a member of North Amerfcan linguistic associations. His work has been published widely on both sides of the Atlantic.

Reprint requests for this or his other articles should be sent to $\mathrm{hm}$ at Jackson Ha11, Faculty of Applied Science, Queen's University, Kingston, Ontario, K7L 3N6. 